\title{
Utilization of cauliflower (Brassica oleracea L. ssp. botrytis) stem flour in improving Balady bread quality
}

\author{
A. E. Hegazy ${ }^{1}$ and M. S. Ammar ${ }^{1, *}$ \\ ${ }^{1}$ Food Science and Technology Department, Faculty of Agriculture, Al-Azhar University, Cairo, Egypt \\ * Correspondence: mohammedammar15@azhar.edu.eg (M.S. Ammar)
}

\section{ABSTRACT}

This study was designed to evaluating the use of cauliflower stems flour (CSF) as partial substitution of wheat flour (WF) at levels of 5, 10,15 and 20\% in Egyptian Balady bread making on farinograph and extensograph properties of the produced doughs, also organoleptic properties, freshness and chemical composition of the produced bread which compared to control wheat bread. Farinograph results showed that as CSF substitution level increased the water absorption and dough weakening increased whereas the mixing time and dough stability were decreased. On the other hand, results of extensograph showed that the dough energy, the resistance to extension, dough extensibility and the proportional number were decreased with increasing CSF level. On the other side, the organoleptic evaluation showed that the substitution of wheat flour with CS Fat level5 \% produce bread similar to the control sample (wheat bread) in all organoleptic properties. Regarding the chemical composition of produced bread, a gradually increase was observed in protein, ether extract, crude fiber and ash contents with increasing the level of added CSF as compared with control bread. Also, results indicated that the cauliflower stems flour improved the bread freshness. It could be concluded that the cauliflower flour can be used to replace $5 \%$ to $10 \%$ of wheat flour in Balady bread making without adverse effect on the consumer acceptability of the bread.

Keywords: Bread; Cauliflower; Chemical composition; Freshness; Rheological; Sensory properties.

\section{INTRODUCTION}

Balady bread is an Egyptian product that represents the main diet component for rich and poor Egyptian consumers. In Egypt, there is a big gap between wheat production and its consumption, where the total production of wheat grains covers only about $55 \%$ of the total needs (Yaseen et al., 2007). Therefore, many researchers studied the possibility of supplementing wheat flour with other cheaper flour (Olaoye et al., 2006).

There are some economically interesting crops such as cabbage, broccoli, cauliflower, and turnip, which have consumed the entire world. A high consumption of these vegetables is associated with a decreased risk of cardiovascular diseases, cancer and degenerative pathologies. Compared to other vegetables, cauliflower has higher antioxidant potential which makes them very interesting crops from the consumer's point of view. It is considered as a rich source of dietary fiber and it possesses both antioxidant and anticarcinogenic properties (Podsedek 2007).

Cauliflower has high waste index, i.e. ratio of non-edible to edible portion after harvesting, and thus generates a large amount of organic solid waste, which creates a foul odor on decomposition. Disposal of the nonedible portion of cauliflower (cauliflower waste), which contributes to about $45-60 \%$ of the total weight of the vegetable, remains a crucial problem (Oberoi et al., 2008).

The main component of the cauliflower is water and it has a low content of carbohydrates, proteins and fats. However, it is considered a good source of dietary fiber, vitamin B6, vitamin B5,folic acid and small amount of other B group vitamins and minerals especially potassium and phosphorous. Cauliflower contains important phytochemicals with its bioactive compounds, glucosinolates and indole-3-carbinol, so cauliflower shows great promise in providing substantial protection against cardiovascular disease, cancer and diabetes. Higher waste to edible ratio and high value of vegetable makes cauliflower one of the best candidates for minimally process ready to cook (RTC) vegetables. Almost $70-80 \%$ of the cauliflower waste (stems and leaves) is reported to have a good nutritive value with respect to proximate composition, digestive crude protein, total digestible nutrient, starch equivalent content 
and amino acids, due to its high nutritive value it can be used as a cereal supplement (Kulkarni et al., 2001; Motey and Lele, 2003). Also, kumar et al. (2017) reported that cauliflower is an excellent source of vitamin C, vitamin $\mathrm{K}$, folate, pantothenic acid, and vitamin $\mathrm{B}_{6}$. It is also a very good source of choline, dietary fiber, omega3 fatty acids, manganese, phosphorus, potassium, magnesium and biotin. Additionally, it had high amount of vitamin $B_{1}, B_{2}, B_{3}$ and protein.

Therefore, this research aimed to study the effect of partial substitution of wheat flour with cauliflower stems flour in producing Balady bread on the rheological properties of the doughs produced from mixed flours and the quality parameters of the produced bread.

\section{MATERIALS AND METHODS}

Commercial wheat flour (Triticumaestivum) (82\% extraction rate), cauliflower (Brassica oleracea), compressed yeast (a Local Strain of Saccharomyces cerevisia) and commercial sodium chloride (Salt) were obtained from the local market. The chemical reagents were purchased from EL- Gamhouria Trading for Chemicals and Drugs Company, Egypt.

\section{Preparation of cauliflower stems flour (CSF)}

Cauliflower stems were washed, blanched by immersing into 3L of boiling water for 3 $\mathrm{min}$. The blanching temperature ranged from 96 to $98^{\circ} \mathrm{C}$. The blanched material was drained for 1 min (Volden et al., 2009) and chopped with a sharp knife to small pieces, then placed in holed salvers and dried in an air oven provided with a motor fan $\left(50-55^{\circ} \mathrm{C}\right.$ for $10-12$ h) till moisture content of 7-8\%. The dehydrated flakes were ground by using a laboratory disc mill (Braun AG Frankfurt Type: KM 32, Germany) to particles 30 mesh as described by Campas-Baypoli et al. (2009).

\section{Preparation of wheat-cauliflower flour blends}

Beside control sample, $(100 \%$ wheat flour, WF), the composite flours were prepared by substituting wheat flour with 5, 10, 15 and 20\% cauliflower stems flour treatments (CSF1, CSF2, CSF3 and CSF4, respectively), then packaged in polyethylene bags and stored in a desiccator until required for further analysis and until processing into Balady bread loaves.

\section{Rheological properties of blended flour mixtures}

Dough samples for the rheological experiments were prepared as those used in bread making, but without added yeast. Farinograph and extensograph properties were assessed according to the method described by A.A.C.C. (2000).

\section{Preparation of bread}

The bread was prepared by mixing 1000 gram of wheat flour (WF) or WF-CSF blends with dried compressed yeast and water at $40^{\circ} \mathrm{C}$, then the produced dough was left at room temperature for $30 \mathrm{~min}$. to complete fermentation, then the dough was cut into loaves, which were baked at $400^{\circ} \mathrm{C}$ for $2 \mathrm{~min}$, in a baker house at the Agriculture Research Center, Giza, Egypt as described by Gallagher et al. (2003). The baked loaves of each treatment divided into two parts one for the sensory evaluation and the other was dried in an oven at $70^{\circ} \mathrm{C}$ for $24 \mathrm{~h}$, finely ground to a powder and stored in plastic bags at freezing temperature $-18^{\circ} \mathrm{C}$ until analyzed.

\section{Organoleptic properties of produced bread}

The organoleptic properties of all bread samples were carried out according to the method of Kramer and Twigg (1974) using the following score values for each characteristic: Appearance (20), Separation of layers (20), Roundness (15), Crumb (15), Crust (10), Taste (10), Odor (10) and Overall acceptability (100).

\section{Gross chemical analyses}

Cauliflower stem flour and Balady bread samples under investigation were analyzed for moisture, Ash, fiber, ether extract and crude protein contents according to the methods of A.O.A.C. (1995). Total carbohydrates were calculated by subtraction.

\section{Freshness of Balady breads}

Freshness of Balady bread loaves was tested after wrapping in polyethylene bags and storage at room temperature for 1,3 and 5 days. It was determined using Alkaline Water Retention Capacity test (AWRC) according to 
the method of Yamazaki (1953), modified by Kitterman and Rubenthaler (1971).

\section{Statistical analysis}

Data was analyzed using the general linear model (GLM) procedure with SAS Version 8.2 software package (SAS, 2003). Multiple T tests were used to separate means at 0.05 significant levels for each test.

\section{RESULTSAND DISCUSSION}

The proximate chemical composition of cauliflower stems flour

Table 1 shows the proximate chemical composition of cauliflower stem flour. Data showed that cauliflower stem flour had high contents of carbohydrates and protein and crude fiber, 51.66 and 24.31 and $10.87 \%$; respectively but contain moderate contents of ash and ether extract, 7.96 and 5.20; respectively. These results are in agree with the findings of Abul-Fadl (2012) who reported the gross chemical composition of white cauliflower by-product powders as moisture (7. $65 \%)$, crude protein $(22.01 \%)$, fat $(4.44 \%)$, ash content $(8.64 \%)$, total dietary fiber $(10.05 \%)$ and total carbohydrates (47.21\%).

Effect of partial replacement of wheat flour with CSF on dough rheological properties: Farinograph properties

Table 2 shows the farinograph properties of the control and WF-CSF blends. The standard farinograph curve obtained from wheat flour dough showed that water absorption of $54 \%$ with mixing time $3 \mathrm{~min}$. The farinograms of tested WF-CSF blends (containing5 to $20 \%$ CSF) showed that water absorption was ranged between 59.0 and $60.5 \%$ which is higher than that of control (54\%). The differences in water absorption were may be due to the greater number of hydroxyl group which exist in the cauliflower fiber structure and allow more water interaction through hydrogen bonding (Rosell et al., 2001). Cauliflower stems flour (CSF) exhibited high water absorption capacity, emulsion activity and bulk density as reported by kumar et al. (2017). Regarding to mixing time, the CSF4containing $20 \%$ exhibited the longest mixing time (4.5 min.), while the blends CSF1 and CSF2 exhibited shorter mixing time (2.5 min.) as compared to control and the blend CSF3which were $3 \mathrm{~min}$.

The dough stability, when 500 BU of consistency is reached, was affected by level of substitution of wheat flour with CSF, since CSF containing samples recorded lower dough stability ( $3 \mathrm{~min}$.) than that of control sample (4 min.) as shown in Table 1. On the other hand, the dough weakening increased proportionally from 110 B.U for control sample to 120 B.U for CSF1 and CSF2 blends, but decreased to 90 and 80 B.U forCSF3and CSF4 blends; respectively.

Generally, the pervious results were coincided with results of Pomeranz et al. (1977).

Table 1. proximate chemical composition of cauliflower stems flour (on dry basis).

\begin{tabular}{cccccc}
\hline Component & Crude protein & Ether extract & Crude fiber & Ash & Total carbohydrates \\
\hline$\%$ & $24.31 \pm 32$ & $5.20 \pm 0.12$ & $10.87 \pm 0.70$ & $7.96 \pm 0.22$ & $51.66 \pm 0.33$ \\
\hline
\end{tabular}


Table 2. Effect of partial replacement on farinograph parameters of control and tested doughs.

\begin{tabular}{ccccc}
\hline Treatments & Water Absorption $(\%)$ & Mixing Time $(\mathrm{min})$ & Dough Stability $(\mathrm{min})$ & Dough Weakening (B.U) \\
\hline Control & 54 & 3.0 & 4 & 110 \\
CSF1 & 59 & 2.5 & 3 & 120 \\
CSF2 & 59.5 & 2.5 & 3 & 120 \\
CSF3 & 59.5 & 3.0 & 3 & 90 \\
CSF4 & 60.5 & 4.5 & 3 & 80 \\
\hline Cof
\end{tabular}

$20 \%$ CSF.

Table 3. Effect of partial replacement on extensograph parameters of control and tested doughs.

\begin{tabular}{ccccc}
\hline Treatments & $\begin{array}{c}\text { Dough } \\
\text { Energy }\left(\mathrm{cm}^{2}\right)\end{array}$ & $\begin{array}{c}\text { Dough } \\
\text { Extensibility }(\mathrm{E})(\mathrm{m} . \mathrm{m})\end{array}$ & $\begin{array}{c}\text { Resistance } \\
\text { to Extension }(\mathrm{R})(\mathrm{B} . \mathrm{u})\end{array}$ & $\begin{array}{c}\text { Proportional Number } \\
(\mathrm{R} / \mathrm{E})\end{array}$ \\
\hline Control & 30 & 110 & 220 & 2.0 \\
CSF1 & 26 & 95 & 185 & 1.95 \\
CSF2 & 20 & 90 & 160 & 1.77 \\
CSF3 & 16 & 75 & 100 & 1.33 \\
CSF4 & 12 & 70 & 80 & 1.14 \\
\hline Control, $100 \%$ wheat flour; CSF1, 95 \% WF/ 5 \% CSF; CSF2, 90 \% WF/ 10 \% CSF; CSF3, 85 \% WF $15 \%$ CSF and CSF4, $80 \%$ WF \\
20\% CSF.
\end{tabular}

\section{Extensograph properties}

Table 3 shows the extensograph properties of control and CSF blends. Data indicated that all parameters were obviously decreased in all CSF blends with increasing the level of cauliflower stem flour added when compared with control and reached to $12 \mathrm{~cm}^{2}, 70 \mathrm{~mm}, 80$ BU and 1.14 in CSF4 blend, for dough energy, dough extensibility, resistance to extension and proportional number; respectively.

Effect of partial replacement of wheat flour with CSF on the organoleptic properties of breads

Table 4 shows the sensory evaluation of control (wheat bread) and bread containing
CSF. Data showed that there were no significant differences between control and breads containing 5 and $10 \%$ of CSF in all sensory characteristics with exception, the crust color, taste and odor of bread that containing $10 \%$ CSF which was significantly reduced $(P<0.05)$ when compared with control bread. But the bread samples containing 15 and $20 \%$ CSF were significantly lower $(P<0.05)$ in all tested properties and had less judging scores as compared to other samples. Since, overall acceptability scores for these samples were 70.5 and 58.4, against 90.8 of control bread. Generally, substitution levels of wheat flour with CSF up to $10 \%$ gave acceptable bread samples.

Table 4. Effect of partial replacement on the organoleptic properties of bread samples.

\begin{tabular}{|c|c|c|c|c|c|}
\hline \multirow[b]{2}{*}{ Property } & \multicolumn{5}{|c|}{ Treatments } \\
\hline & Control & CSF1 & CSF2 & CSF3 & CSF4 \\
\hline Appearance (20) & $19.0^{\mathrm{a}} \pm 0.08$ & $19.0 \mathrm{a} \pm 0.02$ & $18.7 \mathrm{a} \pm 0.04$ & $15.1^{\mathrm{c}} \pm 0.02$ & $12.1^{\mathrm{d}} \pm 0.14$ \\
\hline Separation of layers (20) & $19.0^{a} \pm 0.01$ & $19.0 \mathrm{a} \pm 0.02$ & $19.0^{a} \pm 0.03$ & $15.1^{c} \pm 00$ & $13.2^{\mathrm{d}} \pm 0.23$ \\
\hline Roundness(20) & $14.8^{\mathrm{a} \pm 0.06}$ & $14.6^{\mathrm{a} \pm 0.05}$ & $14.5^{\mathrm{a} \pm 0.10}$ & $14.2^{c} \pm 01$ & $14.3^{\mathrm{b}} \pm 0.11$ \\
\hline Crumb(10) & $9.5^{\mathrm{a}} \pm 0.12$ & $9.4^{\mathrm{a}} \pm 0.04$ & $9.5^{\mathrm{a}} \pm 0.04$ & $7.0 \_ \pm 0.02$ & $5 . .4^{\mathrm{d}} \pm 0.22$ \\
\hline Crust color(10) & $9.5^{\mathrm{a}} \pm 0.02$ & $9.3^{a} \pm 0.02$ & $9.0^{\mathrm{b}} \pm 0.02$ & $7.0 \_ \pm 0.01$ & $5 . .4^{\mathrm{d}} \pm 0.12$ \\
\hline Taste(10) & $9.5^{\mathrm{a}} \pm 0.02$ & $9.2^{\mathrm{a}} \pm 0.02$ & $8.5^{\mathrm{b}} \pm 0.02$ & $6.5^{\mathrm{d}} \pm 0.13$ & $5 . .6^{\mathrm{d}} \pm 0.18$ \\
\hline Odor(10) & $9.5^{\mathrm{a}} \pm 0.03$ & $9.3^{\mathrm{a}} \pm 0.03$ & $8.5^{\mathrm{b}} \pm 0.03$ & $6.0^{\mathrm{d}} \pm 0.02$ & $4 . .2^{\mathrm{d}} \pm 0.21$ \\
\hline Overall acceptability (100) & $90.8^{\mathrm{a}} \pm 0.06$ & $89.0^{a} \pm 0.01$ & $87.5^{\mathrm{b}} \pm 0.04$ & $70.5^{\mathrm{d}} \pm 0.04$ & $58.4^{\mathrm{d}} \pm 0.18$ \\
\hline
\end{tabular}

Control, 100 \% wheat flour; CSF1, 95 \% WF/ 5 \% CSF; CSF2, 90 \% WF/ $10 \%$ CSF; CSF3, 85 \% WF 15\% CSF and CSF4, 80 \% WF $20 \%$ CSF. Values are means of three determinations \pm standard deviation. a, b, c, d: mean values in columns with different letters differ significantly. 


\section{Effect of partial replacement of wheat flour with CSF on the gross chemical composition of Balady breads}

Table 5 shows the chemical composition of control (wheat bread) and bread containing CSF. The results showed that protein, ether extract, crude fiber and ash contents were gradually increased with increasing the incorporation level of CSF as compared with control sample. This alteration could be attributed to the addition of cauliflower stems flour as partial substituting of wheat flour in making bread; which is rich in protein content and the other components. In this regard,
Motey and Lele (2003) and Stojceska et al. (2008) indicated that protein, fat, ash and crude fiber contents of cauliflower flour were higher than those contents of wheat flour. On the other hand, a gradually decrease in total carbohydrates content was noticed and reached to $66.83 \%$ in bread containing $40 \%$ CSF, against $84.68 \%$ of control sample. The above mentioned data are in accordance with those obtained by Thilagam et al. (2011) who reported that white cauliflower by-products powder is considered a good source of protein, minerals and crude fiber.

Table 5. Effect of partial replacement on the gross chemical composition (on dry weight basis) of bread samples.

\begin{tabular}{llllll}
\hline Component $(\%)$ & \multicolumn{5}{l}{} \\
\hline Treatments & Crude protein & Ether extract & $\begin{array}{l}\text { Crude } \\
\text { Fiber }\end{array}$ & Ash & Total Carbohydrates \\
\hline Control & $10.65 \pm 0.07$ & $1.45 \pm 0.02$ & $1.85 \pm 0.02$ & $1.37 \pm 0.03$ & $84.68 \pm 0.11$ \\
CSF1 & $10.73 \pm 0.06$ & $2.17 \pm 0.02$ & $2.97 \pm 0.01$ & $5.36 \pm 0.02$ & $78.13 \pm 0.07$ \\
CSF2 & $12.65 \pm 0.05$ & $2.39 \pm 0.01$ & $3.69 \pm 0.02$ & $6.39 \pm 0.04$ & $74.88 \pm 0.04$ \\
CSF3 & $15.20 \pm 0.04$ & $2.89 \pm 0.04$ & $4.75 \pm 0.01$ & $6.98 \pm 0.03$ & $70.18 \pm 0.02$ \\
CSF4 & $16.73 \pm 0.07$ & $3.24 \pm 0.02$ & $6.20 \pm 0.03$ & $7.62 \pm 0.03$ & $66.83 \pm 0.09$ \\
\hline
\end{tabular}

Control, $100 \%$ wheat flour; CSF1, $95 \%$ WF/ $5 \%$ CSF; CSF2, 90 \% WF/ $10 \%$ CSF; CSF3, $85 \%$ WF 15\% CSF and CSF4, $80 \%$ WF

$20 \%$ CSF. Values are means \pm standard deviations $(n=3)$.

\section{Effect of partial replacement of wheat flour with CSF on the bread freshness}

Freshness of Balady bread loaves was measured by determination of its capacity to retain moisture during a storage period of three days. Table 6indicates the alkaline water retention capacity (AWRC) values of bread samples after baking and at each 24 hours interval for three days. After baking, AWRC value for control bread was 326 as compared to $315,320,320$ and 325 for bread containing CSF at 5, 10, 15 and 20\%; respectively which reduced after $72 \mathrm{~h}$ to $2.65,2.67,2.68$ and 2.70 for the same CSF samples as compared to control value 2.57. It could be noticed that addition of cauliflower stems flour improved bread freshness to the level of control bread.

Table 6. Alkaline water retention capacity (AWRC) of Balady bread samples.

\begin{tabular}{ccccc}
\hline Treatments & After baking & $24 \mathrm{~h}$ & $48 \mathrm{~h}$ & $72 \mathrm{~h}$ \\
\hline Control & 326 & 305 & 2.85 & 2.57 \\
CSF1 & 315 & 318 & 2.90 & 2.65 \\
CSF2 & 320 & 318 & 2.89 & 2.67 \\
CSF3 & 320 & 320 & 2.95 & 2.68 \\
CSF4 & 325 & 319 & 2.85 & 2.70 \\
\hline Control, $100 \%$ wheat flour; CSF1, $95 \%$ WF $/ 5 \%$ CSF; CSF2, $90 \%$ WF $/ 10 \%$ CSF; CSF3, $85 \%$ WF $15 \%$ CSF and CSF4, 80 WF
\end{tabular}
$20 \%$ CSF. 


\section{CONCLUSION}

It could be concluded that the cauliflower stem flour can be used to replace $5 \%$ to $10 \%$ of wheat flour in Balady bread making without adverse effect on the consumer acceptability of the bread. Also, the addition of cauliflower flour increased protein, fat, fiber and ash contents as compared with control wheat bread.

\section{REFERENCES}

A.A.C.C., 2000. Bread firmness by universal testing machine. in: Approved Methods of the A.A.C.C., American Association of Cereals Chemists, St. Paul, MN, P. 74-79.

A.O.A.C., 1995. Official Methods of Analysis of the Association of official analytical chemists 6th ed. Arlington, Virginia.

Abul-Fadl, M.M., 2012. Nutritional and chemical evaluation of white cauliflower by-products flour and the effect of its addition on beef sausage quality. J. Appl. Sci. Res. 8 (2), 693-704.

Campas-Baypoli, O.N., Sánchez-Machado, D.I., BuenoSolano1, C., Núñez-Gastélum, J.A., Reyes-Moreno, C., lópez-cervantes, J., 2009. Biochemical composition and physicochemical properties of broccoli flours. Int. J. Food Sci. Nutr. 60, 163-173.

Gallagher, E., Gormley, T.R., Arendt, E.K., 2003. Crust and crumb characteristics of gluten-free breads. J. Food Eng. 56, 152-161.

Kitterman, J.S., Rubenthaler, G.L., 1971. Assessing the quality of early generation wheat selection with the micro AWRC test. Cereal Sci. Today. 16, 313316.

Kramer, A., Twigg, B.A., 1974. Fundamentals of quality control for the food industry, AVI Publishing Co., West Port, CT.

Kulkarni, M., Motey, R., Lele, S.S., 2001. Biotechnology in agriculture, industry and environment. in: Proceedings of the International Conference of SAARC Countries, Microbiologists Society at Karad, India, December 28-30. p. 24-31.
Kumar, V., Singh, D., Panchbhaiya, A., 2017. Genetic variability studies in mid-season cauliflower (Brassica oleracea var. botrvtis L.). Bull. Environ. Pharmacol. Life Sci. 6, 99-104.

Motey, R., Lele, S.S., 2003. Fresh cauliflower preservation technology. J. Food Sci. Technol. 40, 419-422.

Oberoi, H., Bansal S.S., Dhillon, G.S., 2008. Enhanced $\beta$ galactosidase production by supplementing whey with cauliflower waste. Int. J. Food Sci. Technol. 43, 1499-1504.

Olaoye, O.A., Onilude, A.A., Idowu, O.A., 2006. Quality characteristics of bread produced from composite flours of wheat, plantain and soybeans. Afr. J. Biotechnol. 5, 1102-1106.

Podsedek, A., 2007. Natural antioxidants and antioxidant capacity of Brassica vegetables: A review. LWT Food Sci. Technol. 40, 1-11.

Pomeranz, Y., Shogren, D.M., Finney, F.K., Bechtel, B.D., 1977. Fibre in bread making-effects on functional properties. Cereal Chem. 54, 25-41.

Rosell, C.M., Rojas, J.A., Benedito, B., 2001. Influence of hydrocolloids on dough rheology and bread quality. Food Hydrocoll. 15, 75-81.

SAS, 2003. Statistical Analysis System. SAS Release 9.1 for windows, SAS Institute Inc. Cary, NC.

Stojceska, V., Ainsworth, P., Plunkett, A., Ibanoglu, E., Senol, I., 2008. Cauliflower by-products as a new source of dietary fiber, anti-oxidants and proteins in cereal based ready to-eat expanded snacks. J. Food Eng. 87, 554-563.

Thilagam, V.K., Lalitha, M., Natesan, R., 2011. Integrated nutrient management for sustaining cauliflower productivity- a review. Agric. Rev. 32, 26-31.

Volden, J., Borge, G.I.A., Hansen, M., Wicklund T., Bengtsson, G.B., 2009. Processing (blanching, boiling, steaming) effects on the content of glucosinolates and antioxidant-related parameters in cauliflower (Brassica oleracea L. ssp. botrytis). LWT Food Sci. Technol. 42, 63-73.

Yamazaki, W.T, 1953. An alkaline water retention capacity test for the evaluation of cookie baking potentialities of soft winter wheat flours. Cereal Chem. 30, 242-246.

Yaseen, A.A., Shouk, A.A., Selim, M.M., 2007. Egyptian Balady bread and biscuit quality of wheat and triticale flour blends. Pol. J. Food Nutr. Sci. 57, 2530 . 


\title{
الاستفادة من دقيق القرنيط في تحسين جودة المبز البلدي
}

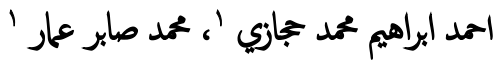

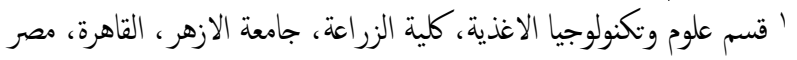

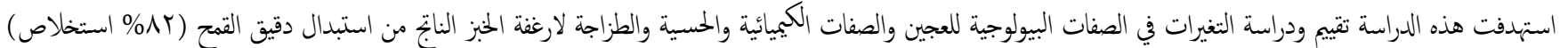

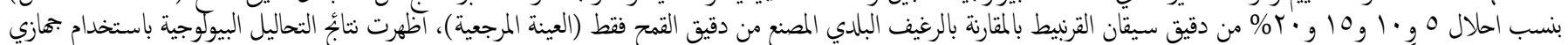

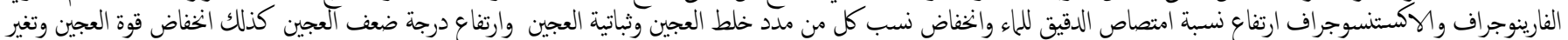

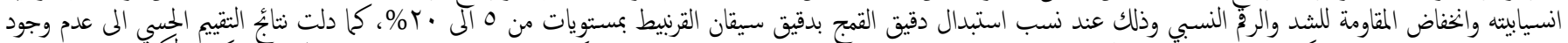

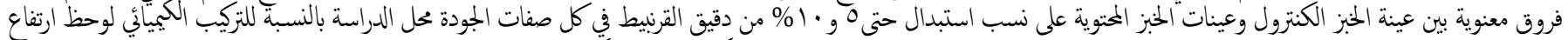

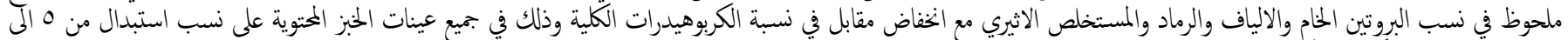

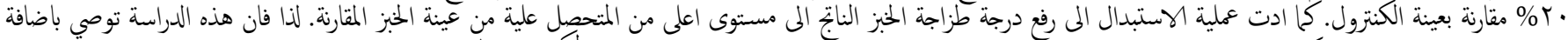

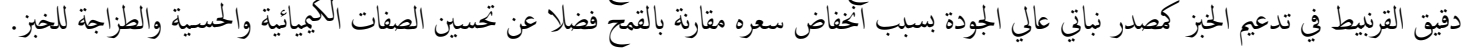

